Chicago-Kent College of Law

Scholarly Commons @ IIT Chicago-Kent College of Law

January 1995

\title{
Beyond Doctrinal Boundaries: A Legal Framework for Surrogate Motherhood
}

Lori B. Andrews

IIT Chicago-Kent College of Law, landrews@kentlaw.iit.edu

Follow this and additional works at: https://scholarship.kentlaw.iit.edu/fac_schol

Part of the Health Law and Policy Commons

\section{Recommended Citation}

Lori B. Andrews, Beyond Doctrinal Boundaries: A Legal Framework for Surrogate Motherhood, 81 Va. L. Rev. 2343 (1995).

Available at: https://scholarship.kentlaw.iit.edu/fac_schol/6

This Article is brought to you for free and open access by the Faculty Scholarship at Scholarly Commons @ IIT Chicago-Kent College of Law. It has been accepted for inclusion in All Faculty Scholarship by an authorized administrator of Scholarly Commons @ IIT Chicago-Kent College of Law. For more information, please contact jwenger@kentlaw.iit.edu, ebarney@kentlaw.iit.edu. 


\title{
BEYOND DOCTRINAL BOUNDARIES: A LEGAL FRAMEWORK FOR SURROGATE MOTHERHOOD
}

\author{
Lori B. Andrews*
}

卫

HERE has been much debate about whether surrogate motherhood should be regulated within the realm of contract law ${ }^{1}$ or family law. ${ }^{2}$ Both sides in the debate have generally used a very simplified view of one doctrine or the other. Some family law professors, for example, argue that contract law should not be applied in surrogacy cases because "parents, unlike courts, cannot make enforceable agreements concerning their child's custody." 3 This distinction begs the question of whether contract principles should be used in certain instances of family relations. It also fails to recognize the many ways in which contract ideas already have entered the family realm. ${ }^{4}$

Those who press for use of the family law model in surrogacy often seem to be applying an idealized model that does not exist in practice,

* Professor of Law and Norman and Edna Freehling Scholar, Chicago-Kent College of Law; Research Fellow, American Bar Foundation.

1 See, e.g., Richard Epstein, Surrogacy: The Case For Full Contractual Enforcement, 81 Va. L. Rev. 2305, 2308 (1995).

2 See, e.g., Carl E. Schneider, Surrogate Motherhood from the Perspective of Family Law, 13 Harv. J.L. \& Pub. Pol'y 125, 126 (1990); see also Alexander M. Capron \& Margaret J. Radin, Choosing Family Law over Contract Law as a Paradigm for Surrogate Motherhood, in Surrogate Motherhood 59 (Larry Gostin ed., 1990) (concluding that surrogate mother arrangements should be handled from the perspective of adoption).

3 Margaret F. Brinig, A Maternalistic Approach to Surrogacy: Comment on Richard Epstein's Surrogacy: The Case for Full Contractual Enforcement, 81 Va. L. Rev. 2377, 2386 n.30 (1995). Similarly, Carl Schneider argues that "contract has never had that kind of prepotence in family law." Schneider, supra note 2, at 126.

4 Private ordering is the approach taken to many important issues in the family realm. In uncontested divorce cases, the parents usually create their own written agreement as to the custody of the children with little or no judicial scrutiny. See Robert H. Mnookin, Divorce Bargaining: The Limits of Private Ordering, 18 U. Mich. J.L. Ref. 1015 (1985); Robert H. Mnookin \& Lewis Kornhauser, Bargaining in the Shadow of the Law: The Case of Divorce, 88 Yale L.J. 950 (1979). Joan Heifetz Hollinger points out that there have even been "many precedents in which courts have honored 'family compacts' providing for the relinquishment of parental rights to a relative in exchange for a promise to support the child, or in exchange for a fee to the surrendering parent." Joan H. Hollinger, From Coitus to Commerce: Legal and Social Consequences of Noncoital Reproduction, 18 U. Mich. J.L. Ref. 865, 894 (1985). For examples of judicial deference to such family decisions, see, e.g., Clark v. Clark, 89 A. 405 (Md. 1913); Enders v. Enders, 30 A. 129 (Pa. 1894). 
one in which women get appropriate respect, their nurturing talents are rewarded by courts, and the best interests of children are effectuated by policy. Given the evidence that women actually fare poorly in the courts in certain family law situations, ${ }^{5}$ it is at least arguable that they might be better off in attorney-assisted before-the-fact negotiations at arm's length rather than waiting to see what remedial crumbs the legal system gives them after the fact. ${ }^{6}$

In addition, a simplistic view of contract law as "a deal's a deal" also does injustice to the role contract principles might play in family arrangements. ${ }^{7}$ The literature on relational contracts suggests that contract principles can bend to accommodate arrangements in which people have bonds other than just market ones. ${ }^{8}$ Contract law need not be the cold, heartless, masculine doctrine that some feminists and family law professors accuse it of being. ${ }^{9}$ Through contract doctrines such as those aimed

5 Mary Becker demonstrates six common judicial biases that disadvantage women in custody decisions purportedly decided on "best interest" grounds. These are biases "(a) against a sexually active mother, (b) against a mother with less money than the father, (c) against a working mother, (d) against a lesbian mother, (e) against a mother involved in an interracial marriage, and (f) in favor of a remarried father." Mary Becker, Maternal Feelings: Myth, Taboo, and Child Custody, 1 S. Cal. Rev. L. \& Women's Stud. 133, 175 (1992).

6 There is reason to believe that women would fare better in ex ante negotiations about surrogate motherhood than they do in ex ante prenuptial negotiations. In the latter situation, the woman is already involved in a relationship. The boundaries of that relationship may be unclear (for example, she may never expect to get a divorce and thus see the agreement as irrelevant). The idea of a prenuptial agreement may have been introduced late in the relationship, possibly on the eve of the wedding, and the woman may feel social, familial, and emotional pressures to go through with the marriage despite her discomfort with the terms of the agreement. In contrast, a potential surrogate mother is not committed to any particular couple (and the couples desperately want a child), so her bargaining power is stronger. The contract at issue does not, as in the prenuptial agreement situation, govern a situation that may never arise, but instead governs the single act that makes up the relationship: bearing a child to turn over to the couple. Consequently, it can be expected that a surrogate will pay more attention to the terms of the contract, will fight harder for her position, and will have more power than would the fiancee in the prenuptial agreement situation.

7 As Patricia Tidwell and Peter Linzer point out, "[t]oday, even the Second Restatement of Contracts, a resolutely middle-of-the-road affair, bristles with phrases like 'as justice requires' .... We have come a long way from the formalism of Williston and the First Restatement of Contracts." Patricia A. Tidwell \& Peter Linzer, The Flesh-Colored Band Aid-Contracts, Feminism, Dialogue and Norms, 28 Hous. L. Rev. 791, $792-93$ (1991).

8 See, e.g., Ian R. Macneil, The Many Futures of Contracts, 47 S. Cal. L. Rev. 691, 723 (1974).

9 The negative way in which some family law professors view contracts is typified by Judith Areen, who asserts that "it is the altruistic ethic of family law that should guide the court, not the ethic of self-gratification of the marketplace and contract law." Judith 
at deterring coercion and minimizing negative externalities, contract law can obtain some of the benefits that are presumed to be gained by a family law approach.

Contract law can also counteract some of the deficiencies that have been identified with family law, such as the fact that it tends to recognize only one type of family: the male-led heterosexual couple with children. ${ }^{10}$ A contract approach to motherhood respects the value of personal intention and contractual commitments in forming relationships. Marjorie Shultz, for example, points out that "intention and contracting is a primary way to build relationships." 11 She notes that currently the law governs the family through public policy by rewarding the "right" kind of intimacy, the "right" kind of family. ${ }^{12}$ Intentionality and contracting can allow a wider range of types of families, such as two women deciding to have a child together via artificial insemination without offering the genetic father a role in rearing the child. A private ordering approach allows women to define themselves and their relationships.

Contract law has its limits, though. Some feminists, disappointed that women have been prevented by discrimination from achieving power in the workplace and political sphere, are understandably reluctant to have women serve as surrogate mothers, thus turning over the power they have in the reproductive sphere to men just because men have mobile sperm and a checkbook. Also, contract principles may conflict with principles of bodily integrity when the contract regulates future behavior (by, for example, requiring that the surrogate have an abortion under certain circumstances). Moreover, by embracing intentionality as a way to project one's plans and commitments, a contract approach requires that the parties have sufficient information and resources to make decisions. Finally, contract law, by focusing on the individual parties, inadequately handles the problem of soft externalities.

Areen, Baby $M$ Reconsidered, 76 Geo. L.J. 1741, 1758 (1988). Carl Schneider notes that the negative view is based on "the sense that contract is an inappropriate way of thinking about family relations, a way that encourages people to behave badly toward each other." Schneider, supra note 2, at 128 .

10 See, e.g., Becker, supra note 5, at 175; Steve Susoeff, Comment, Assessing Children's Best Interests When a Parent is Gay or Lesbian: Toward a Rational Custody Standard, 32 UCLA L. Rev. 852, 862 (1985).

11 Marjorie M. Shultz, Address at the Law and Society Association Annual Meeting (June 17, 1994) [hereinafter Shultz, Address]; see also Marjorie M. Shultz, Reproductive Technology and Intent-Based Parenthood: An Opportunity for Gender-Neutrality, 1990 Wis. L. Rev. 297, 302-03 (1990) (arguing that explicitly bargained-for procreative arrangements should be honored) [hereinafter Shultz, Reproductive Technology].

12 Shultz, Address, supra note 11. 
Because both family law and contract law have their limits, trying to fit surrogate motherhood abstractly into one or the other seems fruitless. ${ }^{13}$ A preferable approach is to explore the experiences of the people directly involved in surrogacy and those people and institutions indirectly involved, identify potential problems, and attempt to create a legal framework that addresses those problems.

Along those lines, I applaud Richard Epstein, whose contract article actually spends more time focusing on the human dynamics and decisions in surrogate motherhood than does the typical family law article on the subject. ${ }^{14} \mathrm{I}$ am, however, more skeptical than he is about whether contract law alone is sufficient to prevent harms in this area. Contract law has its limits. But I would argue that existing doctrines in contract law, tort law, and constitutional law taken together should allow us to feel comfortable with private ordering in surrogacy arrangements.

\section{The Current Statutory Scheme}

Since the decision in In re Baby $M,{ }^{15}$ nearly every state legislature has considered laws to allow, ban, or otherwise regulate surrogate motherhood. Nineteen such laws have been adopted. ${ }^{16}$ Most of the statutes

13 The categorization of particular legal disciplines is somewhat arbitrary, anyway. Andrew Kull points out that as late as 1870 , there was a dispute over whether torts merited consideration as a separate legal category. See Andrew Kull, Rationalizing Restitution, 83 Cal. L. Rev. 1191, 1194 \& n.12 (1995). Surrogate motherhood cases are now included in both family law casebooks and contract casebooks. See, e.g., Robert H. Mnookin \& D. Kelly Weisberg, Child, Family and State: Problems and Materials on Children and the Law 593-612, 809-21 (2d ed. 1989); Edward J. Murphy \& Richard E. Speidel, Studies in Contract Law 680-82 (4th ed. 1991).

14 See Epstein, supra note 1.

15537 A.2d 1227 (N.J. 1988) (holding a surrogate contract unenforceable).

16 See Ala. Code § 26-10A-33 (1992); Ariz. Rev. Stat. Ann. \$ 25-218 (1991); Ark. Code Ann. § 9-10-201 (Michie 1993); D.C. Code Ann. §§ 16-401 to -402 (Supp. 1995); Fla. Stat. Ann. $\$ \S 63.212,742.15$ (West Supp. 1995); Ind. Code Ann. $\S \S 31-8-1-1$ to 31-8-2-3 (Burns Supp. 1994); Iowa Code Ann. § 710.11 (West 1993); Ky. Rev. Stat. Ann. § 199.590 (Michiel Bobbs-Merrill Supp. 1994); La. Rev. Stat. Ann. § 2713 (West 1991); Mich. Comp. Laws Ann. §§ 722.851-.863 (West 1993); Neb. Rev. Stat. § 25-21,200 (1989); Nev. Rev. Stat. Ann. $\S 126.045$ (Michie Supp. 1993); N.H. Rev. Stat. Ann. §§ 168-B:1 to :32 (1994 \& Supp. 1994); N.Y. Dom. Rel. Law § 123 (McKinney Supp. 1995); N.D. Cent. Code §§ 14-18-01 to -07 (1991 \& Supp. 1995); Utah Code Ann. § 76-7-204 (1995); Va. Code Ann. §§ 20-156 to -165 (Michie Supp. 1994); Wash. Rev. Code Ann. \$§ 26.26.210 to .260 (West Supp. 1995); W. Va. Code $\S 48-4-16$ (1995). Only 10 of the 19 statutes explicitly apply to gestational surrogacy. See Ariz. Rev. Stat. Ann. § 25-218(D) (1991); D.C. Code Ann. § 16-401 (Supp. 1995); Fla. Stat. Ann. \$§ 63.212(1)(i), 742.15 (West Supp. 1995); Ind. Code Ann. \$§ 31-8-1-1, 31-8-1-4 (Burns Supp. 1994); Mich. Comp. Laws Ann. § 722.853(i) (West 1993); Nev. Rev. Stat. Ann. § 126.045(4)(a) (Michie Supp. 1993); N.H. Rev. Stat. Ann. § 168-B:1(XII) (1994); N.Y. Dom. Rel. Law $\$ 123$ (McKinney Supp. 1995); Va. Code Ann. § 20-156 (Michie Supp. 
shun the contract law approach and instead lean toward a family law approach by either banning surrogacy arrangements or refusing to honor the contracts.

Arkansas, Florida, and Nevada are the only states to embody the contractual model by allowing the intended parents to be the legal parents, but the Florida and Nevada laws apply only to gestational surrogacy (in which the surrogate gestates the couple's embryo). ${ }^{17}$ The most common regulations-applicable in thirteen jurisdictions-are statutes that take a family-law approach by prohibiting enforcement of paid surrogacy contracts. ${ }^{18}$ The statutes differ, however, in how they tip the balance in the event of a dispute over custody. The Michigan and Washington laws embody a classic family-law approach, making a determination in individual cases based on the best interests of the child. ${ }^{19}$ New Hampshire and Virginia (as well as Florida for traditional surrogacy) have a presumption that the contracting couple are the legal parents, but give the surrogate a

1994); Wash. Rev. Code Ann. $\$ 26.26 .210$ (2) (West Supp. 1995). Restrictions in other states on surrogacy arrangements apparently apply only to situations in which the surrogate is inseminated with the intended father's sperm.

17 See Ark. Code Ann. § 9-10-201 (Michie 1993); Fla. Stat. Ann. § 742.15 to .16 (West Supp. 1995); Nev. Rev. Stat. Ann. \$ 126.045 (Michie Supp. 1993).

18 See Ariz. Rev. Stat. Ann. § 25-218 (1991); D.C. Code Ann. § 16-402 (Supp. 1995); Ind. Code Ann. §§ 31-8-2-1 to -2 (Burns Supp. 1994); Ky. Rev. Stat. Ann. § 199.590(4) (Michie/Bobbs-Merrill Supp. 1994); La. Rev. Stat. Ann. § 2713 (West 1991); Mich. Comp. Laws Ann. $\$ \$ 722.853(i), .855, .859$ (West 1993); Neb. Rev. Stat. $\$ 25-21,200$ (1989); N.Y. Dom. Rel. Law \$ 123 (McKinney Supp. 1995); N.D. Cent. Code §14-18-05 (1991); Utah Code Ann. § 76-7-204(1) (1995); Va. Code Ann. § 20-162 (Michie Supp. 1994); Wash. Rev. Code Ann. \$26.26.240 (West Supp. 1995). Likewise, although the language of the Florida statute is broad, see Fla. Stat. Ann. § 63.212(1)(i) (West Supp. 1995), it probably applies only to traditional surrogacy, because a separate Florida statute governs legal parenthood for gestational surrogacy. The Arizona, Indiana, Michigan, New York, North Dakota, and Utah statutes also void unpaid surrogacy contracts. Ariz. Rev. Stat. Ann. § 25-218 (1991); Ind. Code Ann. $\$ \$ 31-8-2-1$ to -2 (Burns Supp. 1994); Mich. Comp. Laws Ann. $\S \S 722.851(i), .855$ (West 1993); N.Y. Dom. Rel. Law $\S 123$ (McKinney Supp. 1995); N.D. Cent. Code § 14-18-05 (1991); Utah Code Ann. § 76-7-204(2) (1995).

19 See Mich. Comp. Laws Ann. \$722.861 (West 1993); Wash. Rev. Code Ann. $\S 26.26 .260$ (West Supp. 1995). The "best interests" approach is also presumably followed in those states that do not explicitly address how custody will be decided once the contract is declared unenforceable. See Ind. Code Ann. \$\$ 31-8-2-1 to -2 (Burns Supp. 1994); Ky. Rev. Stat. Ann. § 199.590 (Michie/Bobbs-Merrill Supp. 1994); La. Rev. Stat. Ann. § 2713 (West 1991); Neb. Rev. Stat. § 25-21,200 (1989) (providing that the biological father has rights and obligations imposed by law with regard to the child); N.Y. Dom. Rel. Law $\$ 124$ (McKinney Supp. 1995). In Utah, the presumption favors the surrogate, but if a dispute as to custody arises, "best interests" is the prevailing standard. See Utah Code Ann. § 76-7204 (1995). 
certain time period during which to change her mind. ${ }^{20}$ In contrast, in Arizona and North Dakota, the surrogate and her husband are the legal parents of the child. ${ }^{21}$

Four jurisdictions ban surrogacy outright, sometimes in addition to provisions that detail who the legal parents are if parties violate the bans. The District of Columbia ${ }^{22}$ and Arizona ${ }^{23}$ ban surrogacy contracts, and Kentucky and Utah ban payment to a surrogate. ${ }^{24}$ Seven more statesFlorida, Michigan, Nevada, New Hampshire, New York, Virginia, and Washington-ostensibly ban payments to surrogates, but these laws contain wide exceptions that allow surrogates' expenses to be paid. ${ }^{25}$

Virginia and New Hampshire provide an extensive regulatory structure for unpaid surrogacy contracts, which includes medical and psychological screening and a requirement that the contract be submitted to a judge for approval in advance of the pregnancy. ${ }^{26}$ In addition, under both laws there must be a home study of the intended parents, as well as of the surrogate and her husband to determine all four parties' suitability for parenthood, ${ }^{27}$ thus attempting to assure the child a good home, no matter which family he or she ultimately ends up with.

20 See Fla. Stat. Ann. $\$ \S 63.212(\mathrm{i})(2)(\mathrm{a}),(6)(\mathrm{h})$ (West Supp. 1995) (authorizing revocation within seven days of birth); N.H. Rev. Stat. Ann. \$\$ 168-B:23(IV), :25(IV) (1994) (authorizing revocation within 72 hours of birth); Va. Code Ann. $\$ \$ 20-158(D), 20-$ 161(B) (Michie Supp. 1994) (authorizing revocation within 180 days from the last performance of any assisted conception).

21 See Ariz. Rev. Stat. Ann. § 25-218 (1991); N.D. Cent. Code § 14-18-05 (1991). In a recent opinion, the Arizona Court of Appeals found this section of the Arizona Revised Statutes to violate equal protection by apparently allowing the man who provided the sperm to assert legal fatherhood but not the woman who provided the egg. See Soos v. Superior Court, 897 P.2d 1356 (Ariz. Ct. App. 1994).

22 See D.C. Code Ann. § 16-402 (Supp. 1995).

23 See Ariz. Rev. Stat. Ann. § 25-218 (1991).

24 See Ky. Rev. Stat. Ann. $\$ 199.590$ (4) (Michie/Bobbs-Merrill Supp. 1994); Utah Code Ann. \$76-7-204(1) (1995). In contrast, the West Virginia adoption law specifically provides that payments to a surrogate mother do not violate the bans, on payment in connection with an adoption. W. Va. Code § 48-4-16(e)(3) (1995).

25 See Fla. Stat. Ann. $\S \S 63.212(1)(i), 742.15(4)$ (West Supp. 1995); Mich. Comp. Laws Ann. $\$ \S 722.853(a), .859$ (West 1993); Nev. Rev. Stat. Ann. § 126.045(3) (Michie Supp. 1993); N.H. Rev. Stat. Ann. § 168-B:25(V) (1994); N.Y. Dom. Rel. Law § 123(1) (McKinney Supp. 1995); Va. Code Ann. \$\$ 20-156, 20-160(B)(4)-(5) (Michie Supp. 1994); Wash. Rev. Code Ann. $\$ \$ 26.26 .210(1), .230$ (West Supp. 1995).

26 See N.H. Rev. Stat. Ann. § 168-B (1994 \& Supp. 1994); Va. Code Ann. §§ 20-156 to 165 (Michie Supp. 1994).

27 See N.H. Rev. Stat. Ann. \& 168-B:18 (1994 \& Supp. 1994); Va. Code Ann. § 20-160(B) (Michie Supp. 1994). 
Ten jurisdictions focus on the role of the intermediary-prohibiting compensation for bringing together couples and surrogates or otherwise facilitating these arrangements. ${ }^{28}$

Most of the current statutes regarding surrogacy seem to be based on the perception that the practice presents intolerable risks and thus should be discouraged. Many commentators, too, have raised concerns about the risks that surrogate motherhood presents for women and children in general, as well as the risks it raises for specific groups (e.g., the surrogates themselves, the resulting children, the surrogate's other children, racial minorities, and children who might otherwise have been available for adoption). My purpose in this Commentary is to ask the following questions: How likely are the risks that have been posited? How grave are they? Are any legal mechanisms currently in place that would prevent such risks or offer recompense to those who have been harmed?

In attempting to answer these questions, my own work has taken me beyond legal sources and into the lives of over eighty surrogate mothers and intended parents. ${ }^{29} \mathrm{I}$ admit that I went into the interviewing process looking for evidence that the women had been exploited. I was frustrated when the first surrogate mother I interviewed, an intensive care nurse, had a higher income level than mine; she didn't fit my stereotype of a downtrodden, exploited surrogate. Later, when I drove up to the home of a Chicana surrogate in Southern California, a tiny speck of a house in a rundown, gang-ridden area, I thought, "Finally, I've found an example of a woman being taken advantage of." In our interview, though, she

28 See Ariz. Rev. Stat. Ann. \$ 25-218(A) (1991); D.C. Code Ann. § 16-402(b) (Supp. 1995); Fla. Stat. Ann. § 63.212(1)(i)(5) (West Supp. 1995); Ky. Rev. Stat. Ann. \$ 199.590(4) (Michie/Bobbs-Merrill Supp. 1994); Mich. Comp. Laws Ann. § 722.859 (West 1993); N.H. Rev. Stat. Ann. § 168-B:16(IV) (1994); N.Y. Dom. Rel. Law § 123 (McKinney Supp. 1995); Utah Code Ann. \$ 76-7-204(1) (1995); Va. Code Ann. \& 20-165 (Michie Supp. 1994); Wash. Rev. Code Ann. $\$ 26.26 .230$ (West Supp. 1995). In New York, for example, a first offense for facilitating such arrangements results in a civil penalty, but a subsequent offense is considered a criminal offense. See N.Y. Dom. Rel. Law \$123(2)(b) (McKinney Supp. 1995). However, the Florida and Virginia laws provide that lawyers may receive compensation for regular professional services, such as advising on the contract. See Fla. Stat. Ann. \$ 63.212(1)(i)(5) (West Supp. 1995); Va. Code Ann. \$ 20-165(C) (Michie Supp. 1994).

${ }^{29}$ Many of these interviews were done as background research for my previous publications. See Lori B. Andrews, New Conceptions: A Consumer's Guide to the Newest Infertility Treatments, Including In Vitro Fertilization, Artificial Insemination, and Surrogate Motherhood (1984) [hereinafter Andrews, New Conceptions]; Lori B. Andrews, . Between Strangers: Surrogate Mothers, Expectant Fathers, \& Brave New Babies (1989) [hereinafter Andrews, Between Strangers]; Lori B. Andrews, Surrogate Motherhood: The Challenge for Feminists, 16 Law Med. \& Health Care 72 (1988) [hereinafter Andrews, Surrogate Motherhood]. 
impressed me with her decisiveness and commitment. She told me, "I can't feed the hungry, I can't stop war, but I can change the world in a small way by helping a couple become a family." I have a hard time telling that Chicana woman that she is not entitled to act upon her decision-that she, in fact, should go to jail for those sentiments, as she would in those four jurisdictions that currently criminalize surrogacy arrangements. Based on my interviews, other studies of the participants in surrogacy arrangements, and analysis of the existing cases, I found that many of the concerns raised about surrogate motherhood are rashly speculative and bear no relation to the arrangements as they currently exist. ${ }^{30}$ It is useful to examine closely the experiences of the parties in this process in order to assess the merits of the most common arguments that are made against surrogate motherhood.

\section{A. Risks to Women}

Surrogate motherhood has been criticized as presenting intolerable risks to women, including physical risks, psychological risks, and symbolic risks such as objectification and commodification. However, the critics rarely put these risks in context or analyze the disadvantages of policy positions that circumscribe a woman's decisionmaking power in order to protect her against taking risks.

Surrogacy has been criticized as putting women at a physical risk. Carl Schneider points out that "some surrogate mothers will become sick or even die."31 Schneider does not indicate why, given that we allow women to take the risks of childbearing when they themselves plan to rear the child, these risks become more problematic when they are bearing the child for someone else. ${ }^{32}$ Perhaps it is due not to the physical risk, but to the psychological risk that the surrogate might regret her decision. However, the woman who bears a child to rear herself might regret that decision as well. ${ }^{33}$

30 See, e.g., Sherrie Lynne Russell-Brown, Parental Rights and Gestational Surrogacy: An Argument Against the Genetic Standard, 23 Colum. Hum. Rts. L. Rev. 525, 544-45 (1992).

31 Schneider, supra note 2, at 125.

32 It is unquestionable that some women will be harmed by surrogacy arrangements, just as some women will be harmed by other family and reproductive arrangements-such as marriage, abortion, sterilization, and childbearing. Many women are beaten in marriage; others die in childbirth in non-surrogacy settings. Similarly, at least one woman has died as - a result of surrogate motherhood. She decided to become a surrogate despite having a heart condition. See Surrogate Mother Dies of Heart Condition, UPI, Nov. 11, 1987, available in LEXIS, Nexis Library, UPI File.

33 In response to a 1987 poll, five percent of parents said that if they had it to do over again, they wouldn't have children. See Mark Clements Research, Aug. 1987, available in 
Some commentators assert that the chances that the surrogate will be psychologically harmed by the process are very high, ${ }^{34}$ analogizing it to the psychological harm felt by birth mothers giving children up for adoption. ${ }^{35}$ Some surrogates $d o$ regret their decision to bear a child for another couple, as is evidenced by their decision to try to keep the child. Apparently fewer than one percent of surrogates, however, change their mind and make an effort to keep the child, ${ }^{36}$ which is in keeping with data about the women who change their mind about sterilization or abortion. ${ }^{37}$ This is far fewer than the seventy-five percent of biological mothers in the adoption setting who decide to keep the child, ${ }^{38}$ thus calling into question the widespread use of data about the experiences of biological mothers in adoption by opponents of surrogacy.

In many ways, the fact that there is a difference in the experiences of women in the adoption setting and those in the surrogacy setting is understandable. Surrogate mothers are making their decisions about relin-

WL, Poll-C Database. Even more strikingly, in a study in Australia and Wales, $50 \%$ of women said they did not like mothering. See Peter A. Wish, The Family Experience, UPI, Oct. 3, 1983, available in LEXIS, Nexis Library, UPI File.

34 Margaret Brinig implies this in her statement, "women are not programmed to have children and then part with them." Brinig, supra note 3 , at 2383 . She not only assumes that regret is inevitable but contends that "[t]he regret that such a placement causes does not pass away." Id. at 2384.

35 See, e.g., Scott B. Rae, Parental Rights and the Definition of Motherhood in Surrogate Motherhood, 3 S. Cal. Rev. L. \& Women's Stud. 219, 242 (1994).

36 See Andrews, Surrogate Motherhood, supra note 29, at 74. Here is how I arrived at the figure of less than one percent: First, I called the major surrogacy centers to learn how many surrogate births they had facilitated. Then I obtained data from the National Coalition Against Surrogacy (NCAS) listing all legal actions that were brought by surrogates to try to keep the child. Because, at the time, the NCAS offered a referral service of lawyers across the country who were willing to undertake pro bono cases on behalf of surrogates, they had the best list of surrogates challenging these arrangements (because they had information from the state trial court level which is not obtainable from LEXIS or other case retrieval mechanisms). The actual figure is probably much lower than one percent because the denominator was an extreme underestimate of the total number of surrogacy arrangements at the time; surrogacy arrangements were done by private lawyers across the country, not just within the few surrogacy programs that I contacted. I elaborate on the methodology behind the figure because, in using an excerpt from my article in their casebook, Mary Becker, Cynthia Grant Bowman, and Morrison Torrey called the figure into question. See Mary Becker, Cynthia G. Bowman \& Morrison Torrey, Cases and Materials on Feminist Jurisprudence: Taking Women Seriously 461 (1994). These authors give no data suggesting the figure is higher, but apparently are relying on their own viewpoint that surrogacy is an evil thing and therefore women must be victims even if the authors cannot prove it.

37 See Andrews, Between Strangers, supra note 29, at 230.

38 See Hearings on Surrogate Parenting Before the N.Y. Standing Committee on Child Care 18 (May 8, 1987) (statement of Betsy Aigen). 
quishment under much different circumstances. The biological mother in the traditional adoption situation is already pregnant as part of a personal relationship of her own. In many instances, she would like to keep the child but cannot because the relationship is not supportive or she cannot afford to raise the child. She generally feels that the relinquishment is forced upon her (for example, by her parents, a counselor, or her lover). ${ }^{39}$ The biological mother in the surrogacy situation seeks out the opportunity to carry a child who would not exist were it not for the couple's desire to create a child as a part of their relationship. She makes her decision in advance of pregnancy for internal, not externally enforced, reasons. ${ }^{40}$

The difference is reflected in the way surrogates describe their experiences. In my interviews with surrogate mothers, I found that they did not refer to the fetus as "my baby," as do biological mothers in the context of adoption, but as the intended parents' baby. The surrogate mothers said they loved these babies in their bodies, but not as their own children. Rather, they said they loved them as they would a niece, nephew, or godchild. When they talked to their pregnant bellies, they said, "This is what your parents are doing today"-referring to the infertile couple. The fact that surrogates themselves view their position as different from that of biological mothers in the adoption situation should caution policymakers against unthinkingly applying an adoption/familylaw paradigm to the situation.

Beyond the concern about regret, there is a concern that the surrogacy experience will be degrading to women. Surrogacy is often described as an arrangement in which women are used and then abandoned by fertile men. ${ }^{41}$ The actual relationships look much different. In an increasing number of cases, the embryo carried by the surrogate is a product of the couple's sperm and egg, so there is not just a genetic link to the contracting male, but to the contracting female as well. In addition, whether or not the intended mother has provided the egg, the intended mother often has a role in the pregnancy, usually accompanying the surrogate mother to prenatal visits and developing a relationship with her. Psychol-

39 See, e.g., Eva Y. Deykin, Lee Campbell \& Patricia Patti, The Postadoption Experience of Surrendering Parents, 54 Am. J. Orthopsychiatry 271, 273 (1984); Edward K. Rynearson, Relinquishment and Its Maternal Complications: A Preliminary Study, 139 Am. J. Psychiatry 338, 339 (1982).

40 See Hearings, supra note 38, at 18 (statement of Betsy Aigen).

41 See Surrogacy Arrangements Act of 1987: Hearings on H.R. 2433 Before the Subcomm. on Transportation, Tourism, and Hazardous Materials of the House Comm. on Energy and Commerce, 100th Cong., 1st Sess. 26 (1987) (testimony of Gena Corea, CoChair, Nat'l Coalition Against Surrogacy). 
ogist Hilary Hanafin, who has interviewed over 200 couples and 200 surrogates as part of her work at the Center for Surrogate Parenting in California, notes the transformative effects that the relationship can have on both women. ${ }^{42}$ The intended mothers, who have usually been working women, learn about child-rearing from the surrogates and deemphasize career once they have a family. The surrogate mothers, on the other hand, are motivated by the intended mothers to expand their horizons. Many pursue further education or make career advances after being surrogates. ${ }^{43}$

The fact that important relationships develop between the surrogate and the infertile woman or couple is corroborated by other studies. While twenty-two percent of surrogates in one study felt that giving up the baby was the most emotionally troubling part of the arrangement, twenty-five percent found separating from the couple to be the most emotionally troubling aspect. ${ }^{44}$ The fact that the arrangement is viewed as collaborative is indicated by the fact that seventy-five percent of the surrogates interviewed in one study found the most rewarding part of the experience to be the "creation of a family, giving the gift of life, seeing the beautiful baby, or seeing the couple's happiness." 45

Much attention has been focused on the risks of surrogacy for women, while far less attention has been devoted to what the women themselves see as the potential benefits of surrogacy. Certainly, money is a motivation in this realm, as it is in so many other areas of our lives, including other situations in which people are paid to be surrogate parents (such as nannies, workers in daycare centers, foster parents, and teachers in elementary schools). But money is not the deciding factor for women's participation in surrogacy. ${ }^{46}$ The fact that women choose to be surrogates rather than choosing to earn that same (relatively low) amount of money in some other way suggests that there are other motivations. Studies have found that some surrogates have been affected by the plight of infertile family members and friends. ${ }^{47}$ Others enjoyed parenting and wanted

42 Telephone Interview with Hilary Hanafin, Center for Surrogate Parenting (June 20, 1995).

43 See Andrews, Between Strangers, supra note 29, at 71-72.

44 See Kathy Forest \& David MacPhee, Surrogate Mothers' Grief Experiences and Social Support Networks 17 (1989) (unpublished manuscript, available at the Department of Human Development and Family Studies, Colorado State University) (on file with the Virginia Law Review Association).

45 Id. at 13.

46 See Lori B. Andrews \& Lisa Douglass, Alternative Reproduction, 65 S. Cal. L. Rev. 623, 674 (1991).

47 Id. 
to help infertile couples become parents. ${ }^{48}$ Many of the women I interviewed described the tremendous psychic benefits they received from the feeling that they were helping someone meet a joyous life goal. Many viewed themselves as feminists who were exercising reproductive choice and demonstrating an ethic of care. ${ }^{49}$ It seems crass not to try to understand the arrangement from the surrogate's vantage point, in which this type of employment is viewed as a higher calling, like being a health care professional or educator, and may consequently be preferable to working as a check-out clerk in a grocery store or at some other minimum wage job.

Overall, the risks posed by surrogacy to women occur rarely and do not seem significantly different from the risks ordinarily assumed by women in other areas of their lives. Thus, concerns about the risks to women do not seem to be a sufficient basis for banning surrogacy arrangements. ${ }^{50}$

\section{B. Risks to Children}

A similar argument has been made that surrogacy should be banned because of the potential physical, psychological, and symbolic risks to the resulting children. It has been asserted that a surrogate, who will be carrying a child that she will not later rear, will lie about her health or will not take care during pregnancy because she will not care about the subsequent condition of the child. Margaret Brinig, for example, suggests that if a surrogate changes her mind, she could, out of resentment, engage in risky behavior. ${ }^{51}$ The surrogate mothers I interviewed, however, said that they were treating their pregnancies with great care, pointing out that a person who is caring for someone else's child is often more careful than when she is caring for her own child. This observation is in keeping with the fact that they described their relationship with the child as similar to that of an aunt or godmother. There is thus no reason to believe that surrogacy inevitably, or even in a significant minority of cases, would lead to the child being harmed by the surrogate's lack of concern for the child's well-being. ${ }^{2}$

In addition to the risks that the surrogate herself is said to present to the child, commentators arguing against surrogacy allege that the child

\section{Id.}

49 See, e.g., Andrews, Between Strangers, supra note 29, at 10 (statement of surrogate Carol Pavek); id. at 241 (statement of the National Association of Surrogate Mothers).

50 In Part II, infra, I discuss the policies that might be necessary if surrogacy is allowed.

51 See Brinig, supra note 3, at 2389-90.

52 There is only one case of which I am aware in which the surrogate's behavior endangered the fetus. See Noel P. Keane with Dennis L. Breo, The Surrogate Mother 99 108 (1981). 
will be harmed by parents who may not have undergone previous screening with respect to their suitability for parenting. ${ }^{53}$ This risk was brought tragically to the fore when a 26-year-old unmarried man, James Alan Austin, contracted with a surrogate and subsequently beat the resulting child to death. ${ }^{54}$ Such an occurrence is rare because the most common users of surrogacy-infertile couples-are found to be more stable parents than people conceiving normally. ${ }^{55}$ It would seem unreasonable to argue for a total ban on surrogacy based on this remote risk. ${ }^{56}$

Some commentators responded to the Austin case by advocating screening of the potential rearing parents. Such screening is mandatory under the surrogacy laws of Virginia and New Hampshire. ${ }^{57}$ Critics who advocate screening analogize alternative reproduction to adoption. Yet screening for adoption is subject to much criticism for using faulty measures and traditional stereotypes to determine who is fit to be a parent. In addition, the much-touted adoption model has little empirical foundation. As Joan Heifetz Hollinger points out, "[t]he agencies have never been able to demonstrate that those who acquired their children independently

53 It should be noted that some surrogacy programs do turn away infertile couples based on an assessment of their suitability as parents. At the Center for Surrogate Parenting in Beverly Hills, for example, screening of potential rearing parents is undertaken. See Andrews, Between Strangers, supra note 29, at 80-81.

54 See Tamar Lewin; Man Accused of Killing Son Borne by a Surrogate Mother, N.Y. Times, Jan. 19, 1995, at A16.

55 There is considerable information about the couples who use new reproductive technologies because such couples often undergo psychological assessments as part of infertility treatment programs. See, e.g., Machelle M. Seibel, Workup of the Infertile Couple, in Infertility: A Comprehensive Text 1 (Machelle M. Seibel ed., 1990). In one study of 300 married couples entering an in vitro fertilization program, researchers found that most couples "exhibited closer marital relationships, a more conservative approach to life, a higher quality of life, and emotional adjustment and coping comparable to that of a normal population." M.T. Hearn, A.A. Yuzpe, S.E. Brown \& R.F. Casper, Psychological Characteristics of In Vitro Fertilization Participants, 156 Am. J. Obstet. \& Gyn. 269, 273 (1987). There is reason to believe that couples seeking surrogacy are similarly stable because both in vitro fertilization clinics and surrogacy centers are generally willing to provide the service without an adoption-like screening mechanism and because many couples using surrogacy have previously tried in vitro fertilization.

56 When a tragedy of this sort happens, some commentators lose perspective and argue for massively overbroad policy responses. Ethicist Arthur Caplan, for example, opined: "I think making surrogates available to 26-year-old fertile men is crazy. I think what they might need is to be pointed towards the personal ads or a dating service." Robert Sterrett, Quotables: Words of Hoosier Wit and Wisdom, Indianapolis News, Jan. 21, 1995, at A4. If our real concern is the well-being of the child, however, why should it matter whether a man is caring for a child through surrogacy or through a liaison with a date?

57 See N.H. Rev. Stat. Ann. §§ 168-B:18 to :19 (1994 \& Supp. 1994); Va. Code Ann. $\S 20-160(B)$ (Michie Supp. 1994). 
have any less parenting ability than those who acquired children through agencies." 58

Even if screening in the adoption situation were justifiable, there are crucial differences between adoption and surrogate motherhood. In adoption, there is no biological tie between the child and either of the prospective parents. Thus, the screening becomes a substitute for the biological bond in determining who should be allowed to parent a child. In contrast, with surrogate motherhood, there is a biological tie between one or both of the prospective parents and the child. Traditionally, society has considered that biological tie to be a sufficient indicator of parental merit to let a person reproduce and rear a child without prior restraint.

Moreover, it is unclear that screening would actually predict who will be a good parent. ${ }^{59}$ There was apparently nothing in Austin's background that would have signaled to a psychologist affiliated with a surrogacy program (or to an adoption home study worker) that he would be an unfit parent. One need look no further than the expert testimony in In re Baby $M^{60}$ to see how primitive and unscientific current assessments of parental suitability are. The criteria used by the renowned mental health experts in that case to determine who would be a good parent were absurd. Mary Beth Whitehead was criticized as a bad mother because she dyed her hair, did not play pattycake appropriately and let her children play with stuffed animals instead of pots and pans. ${ }^{61}$ The other three principals in the case did not escape expert scorn, either. In fact, most of the expert witnesses managed to condemn all four. Dr. Allwyn Levine, for example, suggested that Mrs. Whitehead was too impulsive and had an exaggerated sense of self-importance; Mr. Whitehead was too passive and deferred to his wife too much; Mr. Stern was introverted; and Mrs. Stern, though a warm and open person, "could be diagnosed as hav-

58 Hollinger, supra note 4, at 890 (citation omitted).

59 Hollinger makes a similar point: "Anyone who has glanced at the case law or literature on the termination of parental rights knows that we have a hard time figuring out which people are unfit parents." Id. at 889 (citation omitted). Moreover, screening also opens up the possibility for an abuse of discretion in which people who would be good parents are nonetheless denied the opportunity because they are not thought to be socially desirable. A Virginia in vitro fertilization clinic chooses "deserving and appropriate" parents, but it is unclear by what expertise or by what right clinic personnel make that assessment. Gena Corea, The Mother Machine: Reproductive Technologies from Artificial Insemination to Artificial Wombs 145 (1985) (citing clinic director Mason Andrews). The director of a British donor insemination clinic once wrote that he would deny access to the procedure to a "couple of mixed colour or even of mixed religious denomination." Bernard Sandler, Donor Insemination in England, 19 World Med. J. 87, 89 (1972).

60537 A.2d 1227 (N.J. 1988).

61 See Andrews, Between Strangers, supra note 29, at 155. 
ing an adjustment disorder with depressive features."62 If such experts were the gatekeepers to parenthood, no one would be allowed to have children, because everyone would be considered unfit for one reason or another.

In the adoption situation, in which there are far fewer infants for placement than there are willing parents, society is willing to tolerate false positives - the potential for turning away people who would be good parents-in the effort to find the best parents for the child. The task with surrogacy is much different, however. If the state were to adopt a rule forbidding someone like Austin from having his own biological child (whether with a surrogate or someone else), the state would have to meet a high standard of proof about the predictive value of the screening, ${ }^{63}$ a standard that the state could not meet based on current methods of predicting parental suitability. Perhaps the only predictor that might be justifiable would be a past history of child abuse. This contingency is unlikely to arise, however, since most people who enter surrogacy programs do so precisely because they have been unable to have children of their own. Moreover, courts may be unwilling to deny someone a chance to have a future child based on past actions toward a different child. ${ }^{64}$ Society is unwilling, for example, to require the sterilization of child abusers to prevent future abuse.

There is also concern that the child might be psychologically damaged by knowing how he or she was conceived. ${ }^{65}$ Carl Schneider suggests that "[c]hildren born of these contracts may feel some bitterness toward both their parents and even some confusion about who their parents are." ${ }^{66}$

62 Id. at 157.

63 The state would have to show that it was furthering a compelling state interest in the least restrictive manner possible. See Roe v. Wade, 410 U.S. 113, 155 (1973); see also Eisenstadt v. Baird, 405 U.S. 438, 453 (1972) ("If the right of privacy means anything, it is the right of the individual, married or single, to be free of unwarranted governmental intrusion into matters so fundamentally affecting a person as the decision whether to bear or beget a child."). Even under the more lax standard of Planned Parenthood v. Casey, 112 S. Ct. 2791 (1992), forbidding someone to have his or her own biological child based on psychological screening would be considered an "undue burden" on procreative liberty. For an in-depth discussion of the constitutional implications of surrogacy and other reproductive technologies, see John Robertson, Children of Choice: Freedom and the New Reproductive Technologies 22-42 (1994).

64 Thus, the surrogacy situation is much different than a determination of parental suitability in the context of a divorce, in which judgments can be made about the parents' treatment of that particular child.

65 See, e.g., Joan Callahan, The Contract Motherhood Debate, J. Clinical Ethics, Spring 1993 , at $82,86$.

66 Schneider, supra note 2, at 125. 
The surrogates I interviewed disputed that view. Surrogate mother Carol Pavek told me:

I don't see how the children could possibly feel anything negative. ... These children will feel special. ... No one accidently got pregnant. No one just had sex with their boyfriend or had fifteen kids and another one came along who they had to place for adoption. There were two couples carefully considering whether or not to bring a child into the world." 67

Another surrogate, Jan Sutton, stated that " $[t]$ he child born of this process is not 'bought,' 'rejected,' 'abandoned,' or 'sold,' but it is 'planned,' 'desired,' 'loved,' 'given,' and 'nurtured' by the adults involved."68

Richard Epstein is correct in pointing out that, in general, the child of the surrogacy arrangement will fare at least as well as one conceived through ordinary reproduction. ${ }^{69}$ Consequently, it would seem difficult to make the argument that these children would have been better off not being born at all than having been born as a result of a surrogacy arrangement.

Currently, the biggest risk to children in the surrogacy context comes not from the actions of either set of parents but from the uncertain status of the law, which (in the case of bans) can cause the resulting children to be stigmatized as the product of a criminal act and (in the case of contract nonenforcement) can lead to the child being subjected to years of litigation to determine who will be considered to be his or her legal parents.

\section{Harm to Children of Surrogates}

A stronger argument might be made about risks of harm to the surrogate's other children who, after all, are already in existence. ${ }^{70}$ Angela Hölder suggests that contract motherhood arrangements may constitute emotional abuse to the surrogates' children who see a half-sibling being "sold." A1 Another commentator asks, "[w]hat about [the surrogate's] other children, who may wonder whether they, too, will be pawned off to another set of parents?"72

67 Andrews, Between Strangers, supra note 29, at 275.

68 Id. at 240.

69 See Epstein, supra note 1, at 2320-21.

70 See Schneider, supra note 2, at 125-26.

71 See Angela Holder, Surrogate Motherhood and the Best Interests of Children, in Surrogate Motherhood, supra note 2, at 77, 84 .

72 Hollinger, supra note 4, at 902 (citation omitted); see also Brinig, supra note 3, at 2384-85 (providing examples of children's fear of being given away by their parents). 
My own interviews with surrogates and their families indicate that the surrogate's children's reactions to the arrangement were influenced by their mother's reaction. It was common for the young children of the surrogate to meet the couple for whom their mother was carrying a baby. Often the surrogate had a photo of the couple on her refrigerator door. One surrogate told her children, "That's Mary and her tummy's broken and so we're going to carry a baby for Mary."73 Surrogate Jan Sutton emphasized to me that she believed her children learned a positive rather than a negative lesson from surrogacy. They saw how a little inconvenience on their part (for example, due to Sutton having to go to a doctor's appointment or being less active later in the pregnancy) provided the chance for great happiness on the part of the couple. ${ }^{74}$ The surrogates' children I interviewed did not fear that they were going to be given up because they knew, from the beginning, that the baby was the couple's child.

\section{Soft Externalities}

What about harms that are less direct than the risks, which I have been discussing, of explicit physical and psychological harm to women and children? Unlike Richard Epstein, I think "soft externalities" are important. ${ }^{75}$ I am concerned about the overall conceptual changes surrogacy might foster, such as emphasizing the "production" in reproduction or enhancing the treatment of children as commodities. However, many of the assertions that surrogacy will cause dangerous conceptual changes are not supported by facts.

Debra Satz suggests that "[c]ontract pregnancy reinforces stereotypes about the proper role of women in the reproductive division of labor."76 That assertion is contestable, however. It may be that banning surrogacy plays more into the stereotype by requiring women to feel a maternal attachment to the child.

The vision of surrogate motherhood as depersonalized production is also not in keeping with the actual practice. Surrogacy opponents raise concerns about the effect on the surrogate and the child of a pregnancy without love and care. ${ }^{77}$ Philosophy Professor Lisa Newton disputes this

73 Andrews, Between Strangers, supra note 29, at 85 .

74 Id. at 260-61. For the viewpoint of the fourteen-year-old son of a surrogate, see id. at 94. For the views of the five-year-old son of a surrogate, see id. at 169.

75 See Epstein, supra note 1, at 2325 ("Soft externalities should always be ignored.").

76 Debra Satz, Markets in Women's Reproductive Labor, 21 Phil. \& Pub. Aff. 107, 127 (1992).

77 In addition, Susan $M$. Wolf suggests that "[o]ne basis for condemning at least commercial if not all surrogacy is that childbearing is not an act that should be undertaken 
image, however: "The evidence is that the surrogates love the children dearly and derive their highest joy from seeing the child in the arms of its mother, the wife of the father, the woman for whom the child was borne. Love is the motive, not something that is set aside."78

Some commentators oppose surrogate motherhood on the grounds that it potentially weakens the biological ties that give children a secure place in the world. ${ }^{79}$ Carl Schneider also sees this as a problem with surrogacy, claiming that it is likely to weaken the sense of "automatic and ineradicable commitment between family members." $80 \mathrm{He}$ argues that "people who think in contract terms about their family relationships are thinking selfishly when they should be thinking altruistically ...."81 Schneider's slur on intended parents is ill-placed. Their motivation in having a child via surrogacy seems at least as altruistic as those who create families in more traditional ways (which often means without the intent to have children and thus hardly with the best interests of the child in mind). It also seems absurd to argue, as Satz does, that using intent rather than biology to determine parenthood will make children less secure. First, biology is not the way parenthood is currently determined with respect to fathers. ${ }^{82}$ Moreover, refusing to enforce surrogacy contracts and relying on biology means that an infant can be subject to a Baby $M$ situation in which her "biological" father and "biological" mother (the surrogate) spend years in court trying to determine who will get custody. ${ }^{83}$ That is hardly a secure situation for a child.

Carl Schneider also suggests that "much of the objection to surrogacy is precisely this sense that it reduces people to commodities and relations to commerce." 84 However, there is no evidence that the couple who pays $\$ 10,000$ to a surrogate is any more likely to treat the child as a commodity than the couple who pays $\$ 10,000$ for a biological mother's expenses during an adoption, or the couple who pays much more than $\$ 10,000$ to an in vitro fertilization doctor. As Marjorie Shultz notes, "[w]e simply say that money is one dimension of human interaction and valuing. The critical issue is not whether something involves monetary exchange as one of its

on a commercial basis. It should be done only for love, not money ...." Susan M. Wolf, Enforcing Surrogate Motherhood Agreements: The Trouble with Specific Performance, 4 N.Y. L. Sch. Hum. Rts. Ann. 375, 383 (1987) (citation omitted).

78 Andrews, Between Strangers, supra note 29, at 254.

79 See, e.g., Satz, supra note 76, at 122.

80 Schneider, supra note 2 , at 131.

81 Id. at 128.

82 See infra note 130 and accompanying text.

83 See Baby $M, 537$ A.2d 1227.

84 Schneider, supra note 2, at 128. 
aspects, but whether it is treated as reducible solely to its monetary features." $" 85$

There is no evidence that surrogacy as currently practiced actually causes conceptual changes of objectification and commodification. As Scott Altman notes, "[t]heorists move too readily from the unobjectionable idea that reality is socially constructed to the mistaken conclusions that reality is therefore either fragile and subject to quick and unpredictable change at the hands of forces beyond our control or fragile and easily manipulable by us." ${ }^{\text {" }}$ Research in cognitive psychology demonstrates how difficult it is to change beliefs, particularly so central a belief as the importance of children. The fact that courts routinely award damages for wrongful death or loss of consortium has not caused all of us to view our spouses in purely monetary terms. I might buy a diamond for a wedding ring and another for resale, but I will feel differently about them. As Altman points out, in such a case-as with surrogacy-"The difference lies in ... emotional states and intentions."87

\section{The Application of Current legal Doctrine to SURROGATE MOTHERHOOD}

Because the impact of surrogate motherhood on women and children does not justify a total ban on surrogate motherhood, ${ }^{88}$ we are faced with the question of what legal policies are necessary to protect the parties if surrogacy does go forward. The main policy goals that concern me are:

\footnotetext{
85 Shultz, Reproductive Technology, supra note 11, at 336.

86 Scott Altman, (Com)Modifying Experience, 65 S. Cal. L. Rev. 293, 297 (1991) (citations omitted).

87 Id. at 317.

88 It seems to me that, insofar as the level of harm to women under current surrogacy arrangements is sufficiently low and similar to other harms that people are allowed to experience in our society, surrogacy should not be banned on the grounds of potential risk. Other commentators may disagree. Setting the level of tolerable risk in any policy arena is difficult, but it is rare to encounter a situation in which social mechanisms are created in order to assure zero risk. In fact, family law is tolerant of a wide array of risks. Licensing parents before they reproduce is not undertaken even though the risk of child abuse is high. According to a 1994 survey conducted by the National Committee for Prevention of Child Abuse, an estimated 47 children per 1000 were reported as being maltreated. See David Wiese \& Deborah Daro, Current Trends in Child Abuse Reporting and Fatalities: The Results of the 1994 Annual Fifty State Survey 3 (1995). Contract law attempts to minimize risks more finely (by, for example, detailing rights and responsibilities in unlikely situations such as war, strikes, and acts of God). Of course, how much risk one is willing to tolerate is a function of what other values are furthered by letting a particular arrangement go forward. I describe elsewhere some of the values that I believe are furthered by rejecting a ban on surrogate mother arrangements. See generally Andrews, Surrogate Motherhood, supra note 29 (reviewing and criticizing the opposition to surrogacy).
} 
(1) assuring that surrogates make informed choices about entering into these arrangements, and minimizing physical and psychological risks to the participants; (2) assuring the certainty of legal parenthood; and (3) protecting the surrogate's bodily integrity during pregnancy. My belief is that current doctrines in contract law, tort law, and constitutional law can accomplish the first and third goals in the contexts of surrogate motherhood and surrogate gestational motherhood as they are currently practiced, but that an amendment to the state paternity acts might be advisable to achieve the second goal-clarifying the parental status of the contracting couple.

\section{A. Assuring Informed Surrogates and Minimizing Risks}

Even if only a few surrogates are currently harmed by the process, the fact that the harm may be profound (i.e. devastation over losing a child the surrogate feels is hers) indicates that policies must be in place to assure that the women who enter into these arrangements do so in an informed and voluntary way. Some commentators assume this is an unrealistic goal because a woman's decision to enter a surrogacy arrangement will invariably be coerced and/or based on inadequate information.

Margaret Brinig argues that "surrogacy contracts are suboptimal because the surrogate cannot ex ante have perfect, or even minimally adequate, information." 89 However, there is no reason to believe potential surrogates lack adequate information under the current private ordering scheme. A typical surrogacy contract explains in great detail the risks of pregnancy, pointing out the potential 1 in 4800 risk of maternal death due to pregnancy, and describes, for each bodily system (the cardiac system, the respiratory system, the urinary system, the endocrine system, the nervous system, the reproductive system, and so forth) the many and varied disorders that pregnancy could cause or aggravate. ${ }^{90}$ Most surrogate mother programs, moreover, take as applicants only those women who have had children before, so that they understand what the experiences of pregnancy and childbirth are like. Additionally, with the vast media attention given to the Baby $M$ case, ${ }^{91}$ surrogate mothers are certainly informed about the possibility that they might feel emotionally attached to the child after it is born. Overall, then, it would seem that surrogates do have sufficient information to make a decision about whether they wish to enter a surrogacy arrangement in the first place.

\footnotetext{
89 Brinig, supra note 3, at 2388 .

90 See Andrews, Between Strangers, supra note 29, at 41-42.

91 In re Baby M, 537 A.2d 1227 (N.J. 1988).
} 
Some commentators claim that surrogates will never have enough information to enter into a binding contract because they do not know how they will feel about the particular child they are consenting to bear. ${ }^{92}$ The New Jersey Supreme Court picked up this characterization, writing that "quite clearly any decision prior to the baby's birth is, in the most important sense, uninformed." 93 Such a situation would create a Catch22 where a person could not give a valid consent to a procedure until after the procedure had taken place. This approach is at odds with the legal doctrine of informed consent, and would preclude people from ever giving informed consent to sterilizations, abortions, sex change operations, heart surgery, and so forth. Moreover, as Alan Wertheimer points out, "[w]e should not say that a woman's judgment cannot be voluntary just because she cannot fully anticipate the consequences of her choice." ${ }^{94}$ By the same token, we can voluntarily consent to something like marriage, the consequences of which cannot be anticipated. ${ }^{95}$ The issue is not whether a party can predict precisely how she will feel but rather whether she is agreeing to enter into the arrangement even knowing she may potentially regret it.

Currently, many of the legal policies governing surrogacy are counterproductive with respect to assuring that potential surrogate mothers are able to make an informed choice. Nine states and the District of Columbia penalize the involvement of an intermediary in paid surrogacy, ${ }^{96}$ as Margaret Brinig recommends in her Commentary in this Symposium. ${ }^{97}$ When Great Britain adopted a similar approach, which allowed surrogacy but forbade payment to lawyers, psychologists, and other professionals, the law created a situation where a woman wanting to be a surrogate could not seek counseling from a psychologist to help her determine whether being a surrogate would be beneficial or traumatic to her.

92 "A parent can be unexpectedly smitten with profound connection to the newborn child at birth, and a parent who tries ... to give a child away, can find it impossible to go through with the parting." Wolf, supra note 77 , at 400 .

93 Baby $M, 537$ A.2d at 1248.

94 Alan Wertheimer, Two Questions About Surrogacy and Exploitation, 21 Phil. \& Pub. Aff. 211, 228 (1992).

95 Id.

96 See Ariz. Rev. Stat. Ann. § 25-218(a) (1991); D.C. Code Ann. § 16-402(b) (Supp. 1995); Fla. Stat. Ann. \$ 63.212(1)(i)(5) (West Supp. 1995); Ky. Rev. Stat. Ann. § 199.590(4) (Michie/Bobbs-Merrill Supp. 1994); Mich. Comp. Laws Ann. \$ 722.859(3) (West 1993); N.H. Rev. Stat. Ann. § 168-B:16(IV) (1994); N.Y. Dom. Rel. Law § 123 (McKinney Supp. 1995); Utah Code Ann. \$ 76-7-204(1) (1995); Va. Code Ann. \$ 20-165 (Michie Supp. 1994); Wash. Rev. Code Ann. $\$ \$ 26.26 .230$ to .250 (West Supp. 1995).

97 See Brinig, supra note 3, at 2396-97; see also R. Alta Charo, Legislative Approaches to Surrogate Motherhood, in Surrogate Motherhood, supra note 2, at 88, 110 (endorsing a similar approach). 
Brinig goes so far as to suggest that intermediaries are not necessary and that infertile couples should create their own surrogacy clearinghouse. ${ }^{98}$ This view seems to ignore completely the realities of the lives and needs of infertile couples, as well as the complexities of finding and screening surrogates. Although some couples may be comfortable running an ad for a surrogate mother, others may not. One couple who had advertised called me to say that they had found a woman who was willing to be their surrogate and that she was moving in with them the following week. They had no idea what to do either-medically or legally. This may be the sort of self-help that Brinig envisions, but there is no question that there are ways in which intermediaries can avert risks in surrogacy arrangements better than can many couples. It may be easier for an intermediary to say no to an inappropriate surrogate than it would be for the couple, and, despite the difficulty in determining who would be a good surrogate, it is more likely that an intermediary who has interviewed dozens or hundreds of surrogates would have a better sense of the sought-after characteristics than would the couple who is only interviewing a few prospective surrogates. Moreover, the intermediary, as a repeat player, would have a better sense of the type of information that should be collected about the surrogate and the type of medical screening that should be required. The existence of an intermediary also provides a mechanism to assure that both sides understand what they are getting into.

There is also no evidence to support Brinig's assertion that intermediaries are engaging in rent-seeking by misleading the couple into thinking they are getting a watertight contract. ${ }^{99}$ In fact, the typical contract does just the opposite, letting the couple know exactly how perilous their legal position is. Bill Handel, the counsel and director of the Center for Surrogate Parenting, tells couples that the procedure might violate criminal laws with respect to paying money in connection with an adoption, advertising for adoption, or even conspiracy. ${ }^{100} \mathrm{He}$ also points out that the couple might lose custody to the surrogate, yet still have to pay child support. ${ }^{101}$ This is probably information that couples could not readily obtain if they engaged in surrogacy without intermediaries. ${ }^{102}$

98 See Brinig, supra note 3, at 2386.

99 See id. at 2394-95.

100 See Andrews, New Conceptions, supra note 29, at 232-33.

101 See id. at 233.

102 Moreover, Brinig is wrong when she makes it appear that no intermediaries are involved in adoption. She states: "In our jurisdictional market, if these middlemen were a good idea, presumably some state would have experimented with them." Brinig, supra 
Even when a woman is sufficiently informed of potential risks, some commentators suggest that her decision to be a surrogate should not be honored since it is not voluntary, but rather is coerced by pressures from the men in her life or by financial pressures. Richard Epstein counters by pointing out that contract law already recognizes coercion as vitiating the consent to contract. ${ }^{103}$ I think it would be useful for feminist scholarship to focus on how coercion should be defined in the context of women's lives; there are undoubtedly examples of situations, not yet recognized by male judges, in which women could be seen to have been coerced. However, our definition of coercion must not be too broad. In actual practice, it does not appear that women have been coerced into being paid surrogates. Rather, women who decide to become surrogates often meet resistance from the men in their lives. When Mary Beth Whitehead first said she wanted to be a surrogate, for example, her husband Richard replied, "No way." 104

Nor does money seem to be overpowering women's decisionmaking abilities. Few surrogates are financially needy. ${ }^{105}$ Surrogacy programs generally require that surrogates have an income above a certain level to avoid the risk that a surrogate will later change her mind and claim she was coerced into the arrangement by money.

Many opponents of surrogate motherhood would nonetheless allow unpaid surrogacy. ${ }^{106}$ Some commentators suggest "unpaid surrogacy is less likely to be regarded as exploitative-not because the exchange of value is fairer, but because the motivation is less tainted."107 Yet it is hard to imagine how the money itself is responsible for all the potential risks attributed to surrogacy. Mary Beth Whitehead admits that she would have been a surrogate even if she had not been paid, so banning payment would not have avoided the human tragedy of the Baby $M$ case.

In fact, I am even more concerned about coercion in the unpaid surrogacy situation. If only paid surrogacy is banned (as it is currently in Ken-

note 3, at 2396. But states have experimented with middlemen; that is what private placement adoption is all about.

103 See Epstein, supra note 1, at 2314.

104 Andrews, Between Strangers, supra note 29, at 127.

105 Most surrogates are employed full-time and occupy a middle-range income bracket. See Andrews \& Douglass, supra note 46, at 673-74 (citing studies).

106 See, e.g., Capron \& Radin, supra note 2, at 59.

107 Wertheimer, supra note 94, at 224 (citation omitted). The passage of laws that ban paid surrogacy but not unpaid surrogacy prompted one surrogate to ask: "Why am I exploited if I am paid, but not if I am not paid?" Andrews, Between Strangers, supra note 29 , at 259. 
tucky and Utah ${ }^{108}$ ), infertile couples will only be able to have a child through this arrangement by pressuring friends or relatives into being a surrogate. A woman in an arm's-length transaction with a stranger, represented by her own lawyer, would likely have more ability to refuse than a friend or relative. ${ }^{109}$ Allowing unpaid rather than paid surrogacy furthers the pressures on women to nurture all others and to care for family members. Moreover, it is disturbing that, in most instances, when society suggests that a certain activity should be done for altruism, rather than money, it is generally a woman's activity. This perpetuates the devaluation of women's activities in a society that is based on a market system.

Few surrogates change their minds and attempt to break the contract, ${ }^{110}$ despite the fact that the law would allow them to do so in almost every state. Yet the emotional taboo against separating mothers and their children has led some policymakers to presume that a woman is not exercising true choice if she decides to bear a child for someone else. The thought that she would willingly part with her offspring may simply be too frightening to credit. So a myth is created that a surrogate is coerced into service by money or insufficient information. Scott Altman observes that " $[\mathrm{t}]$ he magnification of the possibility that surrogates will regret their decision might really be an expression of dismay over the fact that they do not." 111

As Epstein points out, the special nature of surrogacy (the extremely personal nature of the service and the centrality of decisions about procreation to people's identity) has influenced how surrogacy arrangements have developed, as well as the contractual provisions that govern them. ${ }^{112}$ Moreover, even if contract doctrines deterring misrepresentation and coercion were not sufficient to avert risks to the surrogate, the practice would additionally be regulated by tort law. In the tort context, there is evidence that the professionals who facilitate surrogacy will be held to higher-than-usual standards of screening and information provision.

In the Baby $M$ case, a psychologist working for the surrogacy program had interviewed Mary Beth Whitehead in advance of the insemination and concluded that she would have difficulty giving up the child-but neither she nor the Sterns were ever told. Whitehead later sued for mal-

108 See Ky. Rev. Stat. Ann. § 199.590(4) (Michie/Bobbs-Merrill Supp. 1994); Utah Code Ann. \& 76-7-204 (1995).

109 For an example of how a sister pressured to be a surrogate felt her own life was destroyed as a result, see Andrews, New Conceptions, supra note 29, at 185.

110 See supra note 36 and accompanying text.

111 Altman, supra note 86, at 332.

112 See Epstein, supra note 1, at 2307-08 
practice and got a $\$ 36,000$ settlement. ${ }^{113}$ Similarly, when Judy Stiver contracted cytomegalovirus in the course of a surrogacy arrangement, she was found to have a cause of action against the same surrogacy program for failing to screen the man who had provided the sperm. The court held:

[The professionals] who profited from the program, owed affirmative duties to the Stivers and to Malahoff [the contracting father], the surrogacy program beneficiaries. This duty, an affirmative duty of protection, marked by a heightened diligence, arises out of a special relationship because the defendants engaged in the surrogacy business and expected to profit thereby. Keane [the intermediary] owed a duty to design and administer a program to protect the parties, including a requirement for appropriate testing. ${ }^{114}$

The actual practices in the surrogate mother context-and the contract and tort principles that guide them-should assuage many of the concerns about the risks of surrogate motherhood.

\section{B. Assuring Certainty of Legal Parenthood}

Various commentators, including Margaret Brinig in this Symposium, have suggested that the adoption model should be applied to surrogacy and that the surrogate should be allowed to change her mind and assert a parental claim to the child. ${ }^{115}$ Because of the differences between surrogacy and adoption, however, adoption does not provide the appropriate model for assigning parental rights and responsibility. With surrogacy, the child would not exist were it not for the intended parents. As John Lawrence Hill recognizes, "no one but the intended parents stands in the relationship with the child of being the but for cause of the child's existence." 116 Bill Stern made the same point about Baby M: "She came on to this earth because of a dream that Betsy and I had. Without that dream there would have been no contract with Mary Beth-and no Melissa."117 In addition, the couples' intent to parent may actually make them better

113 See Andrews, Between Strangers, supra note 29, at 221-22.

114 Stiver v. Parker, 975 F.2d 261, 268 (6th Cir. 1992).

115 See Brinig, supra note 3, at 2390 \& n.41; Ruth Macklin, Is There Anything Wrong with Surrogate Motherhood? An Ethical Analysis, in Surrogate Motherhood, supra note 2, at 136, 149; Walter Wadlington, Artificial Conception: The Challenge for Family Law, 69 Va. L. Rev. 465, 504, 511-12 (1983). In the most noteworthy case of its kind, the New Jersey Supreme Court applied the New Jersey adoption laws to a traditional surrogacy arrangement. See Baby $M, 537$ A.2d 1227.

116 John L. Hill, What Does it Mean to be a 'Parent'? The Claims of Biology as the Basis for Parental Rights, 66 N.Y.U. L. Rev. 353, 415 (1991).

117 Andrews, Between Strangers, supra note 29, at 263. 
parents. Marjorie Shultz observes, "because parenting involves longterm and multi-faceted commitment, personal intention seems a desirable basis for selecting between two biological claimants who are arguably equally situated." 118

Richard Epstein would enforce the provisions of the contract giving parental rights to the contracting couple, ${ }^{119}$ as is currently the law with respect to traditional surrogacy arrangements in Arkansas and Nevada. ${ }^{120}$ I think such an approach will result in fewer harms to women and children than nonenforcement, which is the legal approach urged by many commentators, ${ }^{121}$ and by those thirteen jurisdictions where statutes ban or make paid surrogacy contracts void and unenforceable. ${ }^{122}$ First, as Epstein notes, if contracts are enforceable, women who are unsure of whether they will be able to turn over the child will not enter these arrangements. ${ }^{123}$ Moreover, from the child's standpoint, allowing the surrogate to change her mind is much different than allowing a biological mother to change her mind in an adoption situation. In adoption, if the biological mother changes her mind, the baby goes home with her and settles into that family. The strangers who had planned to adopt the child have no claim for custody. If a surrogate changes her mind, the child could be subject to years of litigation to determine who his or her parents are, since both the surrogate and the contracting couple have a biological tie to the child.

Enforcing contracts can help demonstrate that children are not fungibile commodities, but unique individuals. Marjorie Shultz notes,

118 Shultz, Reproductive .Technology, supra note 11, at 332.

119 See Epstein, supra note 1, at 2339 ("[W]e need a legal regime where surrogacy contracts will be enforced come hell or high water.").

120 See Ark. Code Ann. § 9-10-201 (Michie 1993); Nev. Rev. Stat. Ann. § 126.045 (Michie Supp. 1993). In addition, if the surrogate is carrying the couple's embryo, courts in other states may be more willing to hold that the couple's parental rights are superior to those of the surrogate. See, e.g., Johnson v. Calvert, 851 P.2d 776 (Cal. 1993).

121 See, e.g., Charo, supra note 97, at 114; see also Elizabeth S. Anderson, Is Women's Labor a Commodity?, 19 Phil. \& Pub. Aff. 71, 71 (1990) (asserting that "commercial surrogacy constitutes an unconscionable commodification of children and of women's reproductive capacities").

122 See Ariz. Rev. Stat. Ann. § 25-218 (1991); D.C. Code Ann. § 16.402 (Supp. 1995); Fla. Stat. Ann. \$§ 63.212(1)(i), 742.15 (West Supp. 1995); Ind. Code Ann. §§ 31-8-2-1 to -2 (Burns Supp. 1994); Ky. Rev. Stat. Ann. § 199.590(4) (Michie/Bobbs-Merrill Supp. 1994); La. Rev. Stat. Ann. § 2713 (West 1991); Mich. Comp. Laws Ann. § 722.853(i), .855, .859 (West 1993); Neb. Rev. Stat. § 25-21,200 (1989); N.Y. Dom. Rel. Law § 123 (McKinney Supp. 1995); N.D. Cent. Code § 14-18-05 (1991); Utah Code Ann. § 76-7-204(1) (1995); Va. Code Ann. § 20-162(A) (Michie Supp. 1994); Wash. Rev. Code Ann. § 26.26.230 to .250 (West Supp. 1995).

123 See Epstein, supra note 1, at 2339. 
"[t]he more every child is unique, the more women and children are neither fungible nor reducible to specific traits, the stronger the claim for specific performance upon breach of any such agreement."124

It is hard to understand what is gained by the surrogate if contracts are unenforceable. This rule turns the parenthood issue into one focused on the best interests of the child, where the biases against women that surface in normal custody cases may be used to award the child to the contracting couple anyway. ${ }^{125}$ The only policy approach that would assure surrogates custody of the child would be a statute providing that the surrogate and her husband were the legal parents. Although such an approach has been adopted in Arizona and North Dakota, ${ }^{126}$ it is hard to justify. ${ }^{127}$ It might give greater power to women, but it is hard to make the claim that the child is better off with the surrogate and a man who never intended to raise the child than with the couple who wanted a child and intended to rear him or her. In addition, to always presume parenthood in favor of the surrogate ignores the importance of intentionality and turns a cold shoulder to the interests of the other woman in the surrogacy arrangements.

Take the case of In re Marriage of Moschetta,${ }^{128}$ decided by the California Court of Appeals. In that case, Cynthia Moschetta was infertile. She and her husband Robert contracted with Elvira Jordan, who was to be inseminated with Robert's sperm, and who agreed, in exchange for a fee of $\$ 10,000$, to give birth and turn over the baby to the Moschettas.

124 Shultz, Reproductive Technology, supra note 11, at 364 .

125 See supra note 5 . There might be an even greater bias against giving custody to surrogates than to other women. Because surrogates often are younger than the contracting couples, they and their husbands are usually in a lower income bracket than the contracting couple. Courts may be inappropriately swayed by this income difference to deny the surrogate custody. In addition, courts may inappropriately view surrogates as "bad" mothers since they had intended originally to give up the child.

126 See Ariz. Rev. Stat. Ann. § 25-218(b) (1991); N.D. Cent. Code § 14-18-05 (1991). The Arizona Court of Appeals recently found this section of the Arizona Revised Statutes to be unconstitutional. See supra note 21 .

127 Some commentators seem to make a "sweat equity" argument to suggest that the surrogate mother should be considered the legal mother. Both Brian Oxman and Anne Goodwin, for example, point out how much the surrogate mother's hormones and blood supply contribute to the development of the fetus she is carrying. See Anne Goodwin, Determination of Legal Parentage in Egg Donation, Embryo Transplantation, and Gestational Surrogacy Arrangements, 26 Fam. L.Q. 275, 281-85 (1992); R. Brian Oxman, Maternal-Fetal Relationships and Nongenetic Surrogates, 33 Jurimetrics J. 387, 389 (1993). Even if the surrogate does contribute more to the arrangement, however, this does not mean she should not be able to make an enforceable arrangement to give up the child.

12830 Cal. Rptr. 2d 893 (Cal. Ct. App. 1994), review denied, 1994 Cal. LEXIS 5623 (Cal. Oct. 13, 1994). 
For the first seven months after the baby was born, Cynthia Moschetta raised baby Marissa as her own. Then Robert left, taking the baby with him. The couple divorced, and the trial court awarded joint custody to Robert and Elvira, the surrogate mother. Cynthia, who had been the parent most involved in the baby's life, was completely shut out. This approach comports with some commentators' views that the surrogate should be able to change her mind-that she is, in essence, the "owner" of the child-but what does it do to Cynthia?

Whenever parents terminate their rights to their children, there is a point in time at which that termination is recognized as final. In some states an adoption is final after six months. The biological mother, after seven months or seven years, may decide she wants the child back. She may present as compelling a picture in her love for the child as did Mary Beth Whitehead in the Baby $M$ case. But we do not reopen adoptions. In surrogacy situations, the point in time at which the change in parental rights should be considered final is before conception.

Enforcement of the child custody provisions of the contract does not run afoul of the legal doctrine prohibiting specific performance of personal service contracts. Since no further physical action on the part of the woman is necessary once the child is born, giving parental rights to the contracting couple is not specific performance of personal services.

Recognizing the pre-conception intent of the parties does not turn the child into a product, as some commentators claim. Once the child is born, he or she is a separate person in his or her own right. The child is not made to seem any more like a product if child-rearing rights and responsibilities are assigned to the intended parents than if they are assigned to the surrogate.

Some commentators argue that recognizing pre-conception intent and giving the father and his wife a legal right to the child fosters the notion that the child is the property of the father. They say the child should belong to its mother. But that argument does not mitigate the concept of property; it merely shifts ownership. ${ }^{129}$

A presumption that the intended parents are the legal parents is not as radical a departure from existing laws as some commentators assert. Despite the argument of some family law professors that legal parenthood has been determined by nature, parenthood is a statutory

129 In fact, many of Mary Beth Whitehead's statements about Baby M, such as "She's mine" (Bob Pat, Recording Contradicts Whitehead, St. Petersburg Times, Feb. 4, 1987, at $1 \mathrm{~A}$ ), and especially "I gave her life. I can take her life away" (quoted in Andrews, Between Strangers, supra note 29, at 134) seem clearly premised on an ownership notion of parenthood. 
construct that (at least in the case of fathers) does not follow from any biological fact, but rather from social conventions. ${ }^{130}$ Already, in thirtyfive states, the statutes have been amended to let the pre-conception intent of the parties govern in the case of artificial insemination. In these states, the sperm donor is not considered to be the legal father of the child; instead, the consenting husband of the sperm recipient is the legal father. ${ }^{131}$ Similarly, five states have statutes recognizing that the intended mother (the egg recipient) in the egg-donor situation is the legal mother. ${ }^{132}$

130 For example, state parentage laws commonly assume that the mother's husband is the father, unless he is sterile. Thus, even if another man can prove he is the biological father, his claim will not generally be recognized. See Michael H. v. Gerald D., 491 U.S. 110 (1989).

131 See Ala. Code § 26-17-21 (1992); Alaska Stat. \$25.20.045 (1991); Ariz. Rev. Stat. Ann. § 12-2451(B) (Supp. 1994); Ark. Code Ann. \$ 9-10-201(a) (Michie 1993); Cal. Fam. Code $\$ 7613$ (West 1994); Colo. Rev. Stat. \$ 19-4-106(1) (Supp. 1994); Conn. Gen. Stat. Ann. §§ 45a-771 to -775 (West 1993); Fla. Stat. Ann. § 742.11(2) (West Supp. 1995); Ga. Code Ann. \$\$ 19-7-21, 43-34-42 (1991 \& 1994); Idaho Code \$ 39-5405 (1993); Ill. Ann. Stat. ch. 750, para. 40/2 (Smith-Hurd 1993); Kan. Stat. Ann. \$ 23-129 (1988); La. Civ. Code Ann. art. 188 (West 1993); Md. Code Ann., Est. \& Trusts § 1-206(b) (1991); Mass. Gen. Laws Ann. ch. 46, § 4B (West 1994); Mich. Comp. Laws Ann. \$ 333.2824(6) (West Supp. 1995); Minn. Stat. Ann. \$ 257.56 (West 1992); Mo. Ann. Stat. \$ 210.824(1) (Vernon Supp. 1995); Mont. Code Ann. § 40-6-106 (1993); Nev. Rev. Stat. Ann. § 126.061(1) (Michie Supp. 1993); N.H. Rev. Stat. Ann. \$ 168-B:3(e) (1994); N.J. Stat. Ann. § 9:17-44(a) (West 1993); N.M. Stat. Ann. § 40-11-6(A) (Michie 1994); N.Y. Dom. Rel. Law § 73 (McKinney 1988); N.C. Gen. Stat. § 49A-1 (1984); N.D. Cent. Code \$ 14-18-03 (1991); Ohio Rev. Code Ann. \$ 3111.37 (Anderson 1989); Okla. Stat. Ann. tit. 10, § 552 (West 1987); Or. Rev. Stat. $\$ 109.243$ (1990); Tenn. Code Ann. § 68-3-306 (1992); Tex. Fam. Code Ann. § 12.03 (West Supp. 1995); Va. Code Ann. \$20-158 (Michie Supp. 1994); Wash. Rev. Code Ann. \$ 26.26.050(1) (West 1986); Wis. Stat. Ann. \& 891.40(1) (West Supp. 1994); Wyo. Stat. § 142-103 (1994). The strength of the concept of pre-conception intent is also demonstrated in donor insemination cases. The Colorado Supreme Court, for example, has indicated that although an artificial insemination statute extinguishes the rights of the donor, the donor could still be considered a legal father if there were a pre-conception agreement to that effect between the donor and the recipient. See In re R.C., 775 P.2d 27, 35 (Colo. 1989); see also McIntyre v. Crouch, 780 P.2d 239, 244-45 (Or. Ct. App. 1989) (holding that an Oregon statute withholding parental rights and obligations from a semen donor would violate the Due Process Clause of the Fourteenth Amendment if the donor could establish the existence of a pre-conception agreement that he would have the rights and responsibilities of fatherhood), review denied, 784 P.2d 1100 (Or. 1989), cert. denied, 495 U.S. 905 (1990).

132 See Fla. Stat. Ann. § 742.11 (West Supp. 1995); N.D. Cent. Code § 14-18-05 (1991); Okla. Stat. Ann. tit. 10, $\$ \$ 554-555$ (West Supp. 1995); Tex. Fam. Code Ann. $\$ \S 12.03$ A to .03B (West Supp. 1995); Va. Code Ann. \$ 20-158(1) (Michie Supp. 1994); see also McDonald v. McDonald, 608 N.Y.S.2d 477, 480 (N.Y. App. Div. 1994) (enforcing preconception intent in an egg donation situation in which a husband in divorce proceedings sought custody on the theory that his wife, the egg recipient, was not the genetic mother). 
Like Richard Epstein, I favor determining legal parenthood according to the intent of the parties at the start of the arrangement and finding the contracting couple, and not the surrogate, to be the legal parents. ${ }^{133}$ Epstein would do so by a straightforward enforcement of the contract, ${ }^{134}$ but it may be preferable to accomplish this objective through an amendment to the state parentage statutes, as has been done with artificial insemination and egg donation. The benefit of recognizing intent through a parentage statute rather than by contract is that legislation would make it less likely that judges would uphold inappropriate contract provisions that attempt to control the surrogate's behavior during pregnancy.

\section{Protecting the Surrogate's Bodily Integrity During Pregnancy}

Despite Richard Epstein's sensitive and scholarly application of the contract doctrines of force, duress, and misrepresentation to surrogate motherhood, he seems to have a blind spot when it comes to the issue of contractual control over the pregnant surrogate. He is willing to enforce those contract provisions that require the surrogate

"to obey all doctor's orders made in the interests of the child's health. These orders could include forcing her to give up her job, travel plans, and recreational activities. The doctor could confine her to bed, regulate her diet rigidly, and order her to submit to surgery and to take drugs." 135

This is the area in which our concern for soft externalities should be highest, because the justification for enforcement of such controls on pregnant surrogates is precisely that which moves us most toward discussing pregnancy as if it were a form of production, the child as if he or she were a product, and the woman as if she were a machine. Epstein's discussion of the obligations imposed upon the pregnant surrogate might have turned me into a surrogacy basher, were it not for the fact that contract law, tort law, and constitutional law provide a basis to avoid Epstein's scheme for enforcing contractual provisions that require surrogate mothers to abort the pregnancy, follow doctors' orders, or undergo a cesarean section at the whim of the contracting couple.

We can take comfort in the fact that even if Epstein has gotten it wrong, contract law has gotten it right. If a court, under traditional contract principles, is not going to grant specific performance to force an opera singer to sing, ${ }^{136}$ it seems highly unlikely that a court would enforce

133 See Epstein, supra note 1, at 2337-38.

134 Id.

135 Id. at 2334 (quoting Elizabeth Anderson, Value in Ethics and Economics 176 (1993).

136 See Lumley v. Wagner, 42 Eng. Rep. 687 (Ch. 1852). 
the abortion, cesarean section, or medical provisions of the surrogacy contract. In fact, even the trial judge in the Baby $M$ case, who was willing to enforce the provisions of the contract turning over the child to the Sterns, noted that the abortion provision would not be enforceable. ${ }^{137}$

Epstein suggests that "the restrictions that are imposed here are in practice no different from those which would ordinarily be required of a mother who wanted to carry a child to term when no surrogacy arrangement was involved,"138 but he is ignoring the recent trend of courts to treat pregnant women like all other competent adults and allow them to refuse physician-recommended interventions. ${ }^{139}$ There are numerous legal grounds for recognizing a woman's right to refuse interventions during pregnancy. There is the common-law (and in some cases, the constitutional) protection of an individual's bodily integrity. ${ }^{140}$ In certain cases, the proposed intervention may violate the woman's First Amendment right to religious freedom ${ }^{141}$ or the woman's right to privacy to make reproductive decisions. ${ }^{142}$ Some critics have also argued that such interventions violate equal protection guarantees, by subjecting women to requirements to act on behalf of their potential offspring while exempting men from similar obligations. ${ }^{143}$ The New Hampshire and Virginia legislatures have codified this approach by mandating that all medical decisions regarding the surrogate and fetus be made by the surrogate. ${ }^{144}$

There are also practical reasons why Epstein's vision of contractual control over pregnant women's behavior will not come to pass. Based on the legal precedents-including the trial court opinion in Baby $M$-surrogacy centers have redrafted their contracts so that they no longer

137 See In re Baby M, 525 A.2d 1128, 1159 (N.J. Super. Ct. Ch. Div. 1987), modified, 537 A.2d 1227 (N.J. 1988).

138 Epstein, supra note 1, at 2335.

139 See, e.g., In re A.C., 573 A.2d 1235, 1237 (D.C. 1990); Doe v. Doe, 632 N.E.2d 326, 335 (IIl. App. Ct. 1994).

140 See, e.g., Union P. Ry. v. Botsford, 141 U.S. 250, 251 (1891) (common law); Superintendent of Belchertown State Sch. v. Saikewicz, 370 N.E.2d 417, 426 (Mass. 1977) (constitutional law); In re Quinlan, 355 A.2d 647 (N.J. 1976) (constitutional law), cert. denied, 429 U.S. 922 (1976).

141 See, e.g., In re Osborne, 294 A.2d 372 (D.C. 1972).

142 See, e.g., Doe v. Doe, 632 N.E.2d 326 (1ll. App. Ct. 1994).

143 See, e.g., Dawn E. Johnsen, The Creation of Fetal Rights: Conflicts with Women's Constitutional Rights to Liberty, Privacy, and Equal Protection, 95 Yale L.J. 599, 613 (1986).

144 See N.H. Rev. Stat. Ann. \$ 168-B:6 (1994); Va. Code Ann. § 20-163(A) (Michie Supp. 1994); see also Fla. Stat. Ann. \& 742.15(3)(a) (West Supp. 1995) (providing similar guarantees for gestational surrogacy). In addition, a Florida law provides that contracts for traditional surrogacy shall not include a provision requiring that the surrogate abort the pregnancy. See Fla. Stat. Ann. \& 63.212(1)(i)(3)(b) (West Supp. 1995). 
require abortion. Another reason it is unlikely that surrogates will be subjected to these physically invasive provisions is that the ethical guidelines of the medical profession now forbid it. The American College of Obstetricians and Gynecologists' guidelines state that the surrogate-not the couple-should have decisionmaking authority during pregnancy. ${ }^{145}$ And more general ACOG guidelines about treating pregnant women recommend against court-ordered obstetrical interventions. ${ }^{146}$

\section{Conclusion}

Richard Epstein argues that contract doctrines alone provide sufficient protection to the participants in surrogacy arrangements, because they appear to assure a sufficient flow of information to potential parties and sufficient protection of the resulting child. I am more reserved in my opinion than Epstein. Although I think that contract law doctrines, in conjunction with existing tort doctrines and constitutional principles, currently provide sufficient protection to the parties involved in surrogacy arrangements (and to the other members of society who may be affected indirectly), I believe that surrogate motherhood is a social experiment that needs to be closely monitored. It could be that the high level of information that is provided to surrogates and couples under the current scheme is a direct result of surrogacy's uncertain legal status, as a way to get the parties to assume the risks, and that diminished information would be provided if surrogacy contracts were legal and fully enforceable. A parallel is evident in the medical arena, where considerable information is provided to patients about experimental therapy, but less information is provided about those same treatments once they enter routine clinical practice.

So I probably would be more tolerant than Epstein of statutes that required the provision of information to participants in surrogacy contracts, if the private ordering approach did not provide it. Along the same lines, I support statutes that require doctors to tell breast cancer patients of the alternatives to radical mastectomy. But with surrogacy, until I see that private transactions are not functioning well, I would not intervene. Even if the practice of surrogacy changes and there is evidence of increased physical and psychological harm to women and children, my first response would not be to ban the arrangement, but to

145 See Ethical Issues in Surrogate Motherhood, ACOG Committee Opinion (Committee on Ethics, American College of Obstetricians and Gynecologists, Washington, D.C.), Nov. 1990, at 5.

146 See Patient Choice: Maternal-Fetal Conflict, ACOG Committee Opinion (Committee on Ethics, American College of Obstetricians and Gynecologists, Washington, D.C.), Oct. 1987, at 1. 
adopt policies that attempt to avert the harm, such as statutory provisions requiring medical screening and psychological counseling of potential surrogates or requiring advance approval of these arrangements by judges before the initiation of the pregnancy.

The current statutes covering surrogacy are, for the most part, wrongheaded. In some instances, they ban surrogacy altogether, although there is insufficient evidence that surrogacy is inherently harmful. In other instances (such as the ban on payment to intermediaries), they deter the flow of information to the participants. Worst of all, most of the statutes leave the child in legal limbo without a clear indication of who his or her legal parents are. Based on the experiences and needs of individuals directly and indirectly affected by surrogacy, a scheme of private ordering would be preferable to the legislative morass that currently exists. 
HeinOnline -- 81 Va. L. Rev. 2376 1995, 